\title{
Priprava celuloznih hidrogelova modificiranih 2-dimetilaminoetil-metakrilatom i srebrovim nanočesticama
}

\author{
R. Blažic, K. Lenac i E. Vidović* \\ Sveučilište u Zagrebu, Fakultet kemijskog inženjerstva i tehnologije \\ Marulićev trg 19, 10000 Zagreb, Hrvatska
}

Ovo djelo je dano na korištenje pod
Creative Commons Attribution 4.0 Creative Commons Attribution 4.0

\begin{abstract}
Sažetak
Hidrogelovi su materijali koji se odlikuju mogućnošću upijanja velike količine vode. Celuloza je vrlo rasprostranjen biokompatibilan i biorazgradljiv polisaharid s hidrofilnim OH skupinama u strukturi koje omogućuju raznovrsne modifikacije. Uvođenjem novih funkcijskih skupina na osnovni polisaharidni lanac moguće je mijenjati svojstva hidrogela kako bi se pripremili hidrogelovi željenih svojstava: antibakterijska svojstva, osjetljivost na vanjske podražaje i slično. U ovom radu provedeno je graftiranje dimetilaminoetil-metakrilata (DMAEMA) na celulozu. Polimerizacija DMAEMA na celulozu provedena je u otapalu $\mathrm{N}, \mathrm{N}$-dimetil acetamid/LiCl uz peroksidni inicijator pri temperaturi od $90{ }^{\circ} \mathrm{C}$ te $\mathrm{N}, \mathrm{N}$-metilen-bis-akrilamid (MBA) kao umreživačem. U pripravljene hidrogelove unesene su i nanočestice srebra, dobro poznate po antibakterijskim svojstvima. Relativni udio PDMAEMA u hidrogelovima određen je pomoću infracrvene spektroskopije. Morfologija osušenih uzorka i prisutnost srebra određene su pretražnom elektronskom mikroskopijom koja je pokazala da je dodatkom PDMAEMA i sušenjem hidrogelova ekstrakcijom zamrzavanjem dobivena vrlo porozna struktura. Na taj način pospješeno je i vezanje nanočestica srebra na hidrogelove. Uzorci kopolimera priređeni sušenjem u sušioniku pokazuju veći stupanj bubrenja u deioniziranoj vodi ( 109 \%) u odnosu na čistu celulozu (80 \%). Isti materijali sušeni ekstrakcijom zamrzavanjem i tako oblikovani u porozne hidrogelove pokazuju znatno veće vrijednosti stupnja bubrenja (256 \% i $505 \%$ ) naspram čiste celuloze (80 \%).
\end{abstract}

\section{Ključne riječi}

Celuloza, dimetilaminoetil-metakrilat, hidrogelovi, nanočestice srebra

\section{Uvod}

Celuloza je najrasprostranjeniji polisaharid u prirodi koji se sve više istražuje za pripravu novih vrsta materijala. Naročito su značajna svojstva biokompatibilnosti i biorazgradljivosti celuloze. Prisutne OH skupine daju hidrofilnost celulozi i omogućuju stvaranje vodikovih veza unutar pojedine ili između različitih molekula celuloze. Posljedično, celuloza je netopljiva u većini otapala. Zbog biokompatibilnosti celuloze brojna istraživanja materijala na osnovi celuloze usmjerena su na njihovu primjenu u dostavi lijekova i tkivnom inženjerstvu. Međutim, s obzirom na slabu topljivost celuloze, u takvim istraživanjima češće su zastupljeni derivati celuloze poput karboksimetil-celuloze ili hidroksimetil-celuloze. ${ }^{1-4}$ Osim derivata celuloze u pripravi materija za dostavu lijekova ili tkivno inženjerstvo često su zastupljeni različiti oblici celuloze kao što su mikroceluloza (mikrokristalna celuloza, celuloza u obliku mikrovlakana) ili nanoceluloza te, primjerice, celuloza bakterijskog podrijetla. ${ }^{5-7}$ Nadalje, istražuju se mogućnosti izrade trodimenzionalnih umreženih struktura (hidrogelova) iz različitih vrsta celuloze i njezinih derivata. Također, često se uz celulozu upotrebljavaju i drugi polimeri kako bi se postigla željena fizikalno-kemijska svojstva materijala. . $^{8-10}$

*Autor za dopisivanje: prof. dr. sc. Elvira Vidović

e-pošta: evidov@fkit.hr

Rad je prezentiran na VII. hrvatskom simpoziju o kemiji i tehnologiji

makromolekula 2019.
Poli(dimetilaminoetil-metakrilat) (PDMAEMA) sintetski je polimer koji se istražuje za primjene u materijalima $s$ antibakterijskim svojstvima. Tercijarna aminska skupina prisutna u PDMAEMA lako se protonira u kiseloj sredini, što omogućava promjenu svojstava materijala koji sadrže PDMAEMA s promjenom $\mathrm{pH}$ kao vanjskog podražaja. Lin $i$ sur. ${ }^{11}$ priredili su micele na osnovi kopolimera PDMAEMA, gdje su PDMAEMA koristili kao redukcijsko sredstvo za dobivanje srebrovih nanočestica iz $\mathrm{AgNO}_{3}$ pri čemu nastaju kvaterne amonijeve skupine. Pripremljene micele pokazale su antibakterijska svojstva i dobru citokompatibilnost. PDMAEMA se primjenjuje i u pripremi materijala za dostavu lijekova. Dragan i sur. ${ }^{12}$ pripremili su interpenetrirajuće mreže na bazi PDMAEMA i škroba. Na profil otpuštanja pripravljenog materijala znatno je utjecao pH. Kod nižeg $\mathrm{pH}$ zabilježeno je sporije otpuštanje aktivne tvari, dok je kod oko pH 7 zabilježeno brže otpuštanje. Wei i sur. ${ }^{13}$ sintetizirali su hidrogel na bazi PDMAEMA i polisaharida salecana kao potencijalnog materijala za dostavu lijekova. Utvrdili su da hidrogel nije citotoksičan te je, za razliku od prethodnog sustava, veće otpuštanje lijeka zabilježeno kod $\mathrm{pH} \mathrm{1,2} \mathrm{nego} \mathrm{kod} \mathrm{pH} \mathrm{7,4.}$

Srebro je od davnina poznato po svojim antimikrobnim svojstvima. U novije vrijeme ispitivano je djelovanje srebrovih nanočestica protiv mikroorganizama: gram-pozitivnih i gram-negativnih bakterija (E. coli, S. aureus, S. epidermis, L. mesenteroides, B. subtilis, K. mobilis, K. pneumonia itd.), gljivica (A. niger, C. albicans, S. cerevisia, T. mentagrophytes, P. citrinum) te virusa (Hepatitis B, HIV-1, respiratorni 
sincicijski virus (RSV) itd.). ${ }^{14}$ Čestice metala nanodimenzija često pokazuju jedinstvena ili promijenjena fizikalna, kemijska i biološka svojstva u usporedbi s česticama makrodimenzija kao posljedicu velikog omjera površine u odnosu na volumen čestice. Slično je opaženo i u slučaju srebra jer nanočestice srebra imaju iznimno veliku površinu za interakciju koja im omogućava bolji kontakt s mikroorganizmima. Osim veličine čestica na primjeru djelovanja protiv gram-negativnih E. coli utvrđen je značajan utjecaj i oblika nanočestica. ${ }^{15} \mathrm{Kad}$ je ispitivan doprinos dodatka biološki sintetiziranih srebrovih nanočestica protiv $S$. aureus i E. coli, učinkovitost većeg broja antibiotika bila je znatno povećana. ${ }^{16}$

Metalne nanočestice najčešće se dobivaju kemijskim ili fizikalnim metodama. Za pripravu srebrovih nanočestica najčešće se primjenjuje metoda kemijske redukcije u obliku stabilnih koloidnih disperzija u vodenim i organskim otapalima. Opće poznati reducensi su borhidridi, citrati, askorbati i vodik. Na početku, redukcija raznih kompleksa koji sadrže $\mathrm{Ag}^{+}$ione dovodi do stvaranja srebrovih atoma $\left(\mathrm{Ag}^{0}\right)$, što je praćeno aglomeracijom u oligomerne skupine koje dovode do stvaranja koloidnih Ag čestica. ${ }^{17}$ lako se tim postupcima najbolje kontrolira veličina i oblik čestica, one nisu sasvim pogodne za upotrebu u medicinske svrhe. Unaprjeđenje sinteze nanočestica srebra od velikog je interesa osobito s obzirom na biomedicinsku primjenu.

Širenje spoznaja o mogućnostima i prednostima zelene kemije dovodi do razvoja alternativnih, ekološki prihvatljivih metoda sinteze nanočestica srebra te je biosinteza nanočestica prepoznata kao zasebna grana u razvoju nanotehnologije. Metode koje uključuju mikroorganizme, biljne ostatke ili biljne ekstrakte nude se kao jednostavne alternative kemijskoj i fizikalnoj sintezi. U takvim postupcima nisu potrebne visoke temperature i tlakovi, manja je potrošnja energije, izbjegavaju se štetne kemikalije i, u konačnici, postižu se velike financijske uštede. ${ }^{18,19}$ Redukcija srebrovih iona provodi se kombinacijom biomolekula iz ekstrakta kao što su enzimi/proteini, aminokiseline, polisaharidi, vitamini, alkaloidi, flavonoidi itd., koji su neškodljivi za okoliš, ali su sposobni dati elektron za redukciju $\mathrm{Ag}^{+}$ u elementarno srebro $\left(\mathrm{Ag}^{0}\right)$. Redukcijom srebrovih iona iz kompleksa nastaju atomi srebra, koji nakon toga aglomeriraju i, u konačnici, stvaraju stabilne nanočestica srebra. Postupak sinteze upotrebom biljnog ekstrakta vrlo je jednostavan i zahtijeva manje uloženog vremena, ali disperzija nanočestica nije uvijek uniformna.

U ovom radu priredili smo hidrogelove na osnovi celuloze i celuloze graftirane sa funkcijskim monomerom dimetilaminoetil-metakrilatom (DMAEMA) te ih naknadno modificirali uvođenjem srebrovih nanočestica. Srebro je poznato po antibakterijskom djelovanju, a također ima i katalitičku primjenu, pa bi takav hidrogel mogao poslužiti, na primjer, kao nosač katalizatora. Takvim kombiniranjem tvari različitih karakteristika pruža se mogućnost stvaranja novih materijala prestižnih svojstava za vrlo različite primjene, od senzora do različitih nosača i prevlaka, od farmacije, medicine, industrije obrade voda i slično.

\section{Eksperimentalni dio}

\subsection{Materijali}

$U$ radu je upotrijebljena mikroceluloza $(2-10 \mu \mathrm{m})$ (Sigma Aldrich), monomer dimetilaminoetil-metakrilat (DMAEMA) (Röhm GmbH), umreživalo N,N-metilen-bis-akrilamid (MBA) (99\%, Sigma-Aldrich Co.), inicijator Trigonox 21 (tert-butil-peroksi-2-etilheksanoat), (70 \%, Akzo Nobel), otapalo N,N-dimetilacetamid (DMAc) (BDH Prolabo) i litijev klorid (Acros Organics), fosfor pentoksid (BDH Prolabo), etanol (etilni alkohol) (96\%, KEFO d. o. o.), srebrov nitrat $\left(\mathrm{AgNO}_{3}\right)$, ružmarin (sjeckani, sušeni) (KOTÁNYI GmbH), ultračista voda (oznaka: mQ, vodljivost $18 \mu \mathrm{S} \mathrm{cm}^{-1}$ ).

\subsection{Priprema uzoraka}

\subsubsection{Priprava hidrogelova na bazi celuloze}

Mikroceluloza (2 - $10 \mu \mathrm{m})$ je prije otapanja sušena u sušioniku pri temperaturi od $90{ }^{\circ} \mathrm{C}$ u prisustvu fosfor pentoksida $\left(\mathrm{P}_{2} \mathrm{O}_{5}\right)$ do stalne mase. Nakon sušenja pripremljene su otopine 5 mas.\% celuloze u sustavu otapala N, N-dimetilacetamid (DMAc)/litijev klorid (LiCl). Reakcijska smjesa najprije se zagrijava $2 \mathrm{~h}$ na temperaturi od $120{ }^{\circ} \mathrm{C}$ a zatim se miješa još $1 \mathrm{~h}$ pri $100{ }^{\circ} \mathrm{C}$, nakon čega se prebacuje iz uljne kupelji na magnetsku miješalicu i suspenzija se nastavlja miješati pri sobnoj temperaturi 1 dan dok otopina ne postane prozirna. Iz jednog dijela te otopine pripravljene su celulozne sfere koje će se u daljnjim analizama uspoređivati s uzorcima hidrogelova koji su priređeni iz celuloze graftirane $\mathrm{s}$ dimetilaminoetil-metakrilatom. Otopina 5 mas.\% celuloze dokapava se u etanol i pritom nastaju sfere koje je potrebno ispirati novim obrocima etanola u trajanju od oko 3 dana. Nakon toga sfere se prebacuju u deioniziranu vodu.

Odvagama monomera dimetilaminoetil-metakrilata (DMAEMA) i umreživala N,N-metilen-bis-akrilamida (MBA) dodavan je $1 \mathrm{~g}$ otapala DMAc kako bi se osigurala bolja topljivost umreživala. Početna masa celuloze bila je $0,5 \mathrm{~g}$, a drugi reaktanti računati su u odnosu na nju (tablica 1). Upotrijebljen je peroksidni inicijator Trigonox 21. Priprema se 1 mas.\% otopina inicijatora s obzirom na ukupnu količinu monomera DMAEMA i umreživala MBA. Inicijatoru se radi bolje topljivosti dodaje 0,5 g otapala DMAc. Tako pripravljena otopina dodaje se 15 min prije ili poslije dodatka smjese monomera u otopinu celuloze 5 mas.\%. Reakcija polimerizacije DMAEMA u prisustvu celuloze i MBA umreživala provođena je pri temperaturi od $90{ }^{\circ} \mathrm{C} \mathrm{uz}$ stalno miješanje u trajanju od 3 ili 5 h. Pretaloživanje reakcijske smjese provodi se u etanolu ili deioniziranoj vodi. Smjesa se dokapava u neotapalo pomoću kapaljke kako bi se formirao hidrogel u obliku jednolikih sfera. Hidrogel je potrebno ispirati novim obrocima neotapala dok se ne obezboji što traje oko 3 dana.

\subsubsection{Sušenje hidrogelova}

Sušenje priređenih sfera provedeno je usporedno sušenjem u sušioniku i u kriostatu Julabo FP80. Sušenje hidrogela u kriostatu provedeno je tako da je u čašu odvagan približno $1 \mathrm{~g}$ pripravljenih sfera hidrogela i odstranjen višak vode pomoću filtar papira. U Erlenmeyerovu tikvicu ulije 
se $35 \mathrm{ml}$ etanola a potom se tikvica i čaša s hidrogelom uranjaju u kriostat koji je prethodno ohlađen na $-40{ }^{\circ} \mathrm{C}$. Hlađenje hidrogela i etanola traje $30 \mathrm{~min}$ a nakon $30 \mathrm{~min}$ ohlađeni etanol se ulije $u$ čašu $s$ hidrogelom koja je uronjena u kriostat. Takvo zamrzavanje nastavlja se još 5 min a nakon toga se čaša s hidrogelom i etanolom stavlja u zamrzivač. Nakon 24 h etanol se dekantira, dodaje se novi obrok hladnog etanola $(35 \mathrm{ml})$ te se zamrzavanje provodi još jedan dan. Potom se etanol dekantira i hidrogel se suši na zraku pri sobnoj temperaturi oko 1 dan.

\subsubsection{Priprava srebrovih nanočestica}

Sinteza srebrovih nanočestice provedena je redukcijom otopine srebrova nitrata $\left(\mathrm{AgNO}_{3}\right)$ s prethodno priređenim ekstraktom ružmarina. $10 \mathrm{ml}$ otopine srebrova nitrata (10 $\mathrm{mmol}^{-1}$ ) razrijedi se s $80 \mathrm{ml} \mathrm{mQ}$-vode, dok se $5 \mathrm{~g}$ ohlađenog ekstrakta ružmarina razrijedi s $10 \mathrm{ml}$ mQ-vode. Tako pripravljen ekstrakt ružmarina dokapava se u razrijeđenu otopinu srebrova nitrata, a sinteza srebrovih nanočestica provodi se pri sobnoj temperaturi. Tijekom trajanja reakcije sinteze nanočestica Ag uzimani su alikvoti reakcijske smjese u određenim vremenskim intervalima kako bi se pratio tijek nastajanja nanočestica pomoću UV-Vis spektrofotometra. Nakon sinteze Ag nanočestica pripravljena suspenzija skladišti se u hladnjak.

\subsubsection{Priprava hidrogela sa srebrovim nanočesticama}

Sinteza hidrogelova sa srebrovim nanočesticama provedena je bubrenjem hidrogelova $u$ a) suspenziji nanočestica srebra ili b) otopini srebrova nitrata.

Nekoliko sfera odabranih hidrogelova osušenih metodom ekstrakcije zamrzavanjem i u sušioniku odvoje se u bočice i u svaku se dodaje približno 8 g suspenzije nanočestica srebra ili otopine srebrova nitrata $\left(10 \mathrm{mmol} \mathrm{I}^{-1}\right)$. Takvo bubrenje hidrogelova provodi se $u$ trajanju od 1 dan pri sobnoj temperaturi nakon čega se hidrogelovi izdvajaju iz suspenzije i ostavljaju sušiti na zraku oko 2 dana. Nabubrene hidrogelove nije potrebno ponovno sušiti metodom ekstrakcije zamrzavanjem jer sušenjem na zraku ostaje očuvana porozna struktura sfera hidrogela.

\subsection{Karakterizacija priređenih materijala}

\subsubsection{Infracrvena spektroskopija (FTIR)}

FTIR spektri snimljeni su na uređaju Perkin Elmer, Spectrum One. Svi uzorci hidrogelova snimljeni su metodom prigušene totalne refleksije (engl. attenuated total reflection, ATR). Mjerno područje za ATR metodu je između $4000 \mathrm{~cm}^{-1}$ i $650 \mathrm{~cm}^{-1}$ sa spektralnom rezolucijom od $4 \mathrm{~cm}^{-1}$. Da bi se povećao odnos signala prema šumu, uređaj snima svaki spektar četiri puta.

\subsubsection{UV/Vis spektroskopija}

Na UV/Vis spektrofotometru Shimadzu UV-1800 snimljeni su uzorci suspenzije nanočestica srebra u području spektra od 300 do $700 \mathrm{~nm}$. Prije snimanja uzorci su razrjeđivani deioniziranom vodom tako da se u 0,5 g uzorka suspenzije nanočestica srebra doda 4,5 ml deionizirane vode.

\subsubsection{Bubrenje hidrogelova}

Bubrenje hidrogelova provedeno je u deioniziranoj vodi pri sobnoj temperaturi. Tri sfere za pojedini odabrani hidrogel izvagane su i prenesene u bočice uz dodatak odgovarajuće količine vode. Sfere su bubrene u intervalu od $4 \mathrm{~h}$. Sfere hidrogela vađene su iz vode u određenom vremenskom razmaku, papirnatim ubrusom uklonjen je višak vode, a nakon toga su sfere vagane na analitičkoj vagi.

Stupanj bubrenja hidrogelova predstavlja srednju vrijednost jer su za svaki hidrogel bubrene po tri sfere, a određen je prema jedn. (1):

$$
\alpha=\frac{m_{t}-m_{0}}{m_{0}} \times 100 \%
$$

gdje je $\alpha$ oznaka za stupanj bubrenja (\%), $m_{0}$ masa suhog hidrogela prije početka mjerenja stupnja bubrenja $(\mathrm{g}), \mathrm{a} \mathrm{m}_{\mathrm{t}}$ masa nabubrenog hidrogela nakon vremena $t(g)$.

\subsubsection{Skenirajuća elektronska mikroskopija (SEM)}

Osušeni uzorci hidrogelova (aerogelovi) napareni su radi povećanja vodljivosti legurom zlata i paladija prije snimanja na elektronskom pretražnom mikroskopu. Snimanje uzoraka provedeno je na uređaju Tescan Vega 3 pri naponu od $20 \mathrm{kV}$. Morfologija uzoraka aerogelova ispitana je pomoću detektora sekundarnih elektrona (engl. secondary electron, SE), a prisutnost srebra na površini i u unutrašnjosti hidrogelova određena je pomoću energijsko disperzivnog spektrometra (engl. Energy Dispersive Spectrometer, EDS). EDS mjerenje je provedeno pri povećanju od 100 do 150 puta na tri mjesta na uzorku, pri čemu je analizirana površina u obliku kvadrata.

\section{Rezultati i rasprava}

\subsection{Priprava hidrogelova}

Sintetizirani hidrogelovi prilikom pretaloživanja u deioniziranu vodu oblikovani su u sfere, zatim ispirani i sušeni ekstrakcijom zamrzavanjem (slika 1). Iznimno, kod hidrogelova HG 1e i HG 2e pretaloživanje i oblikovanje u sfere provedeno je u etanolu.

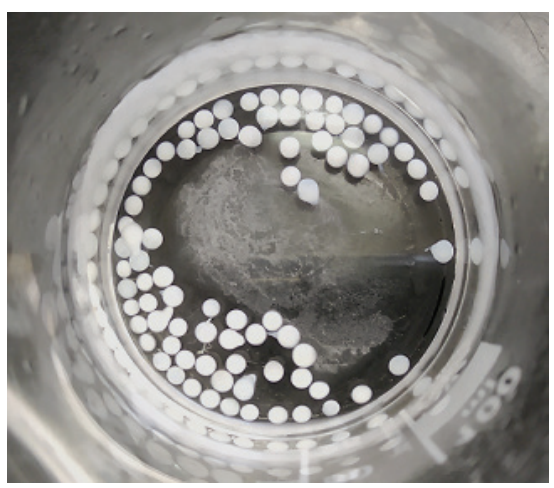

Slika 1 - Sfere pripravljenog hidrogela Fig. 1 - Spheres of prepared hydrogel 


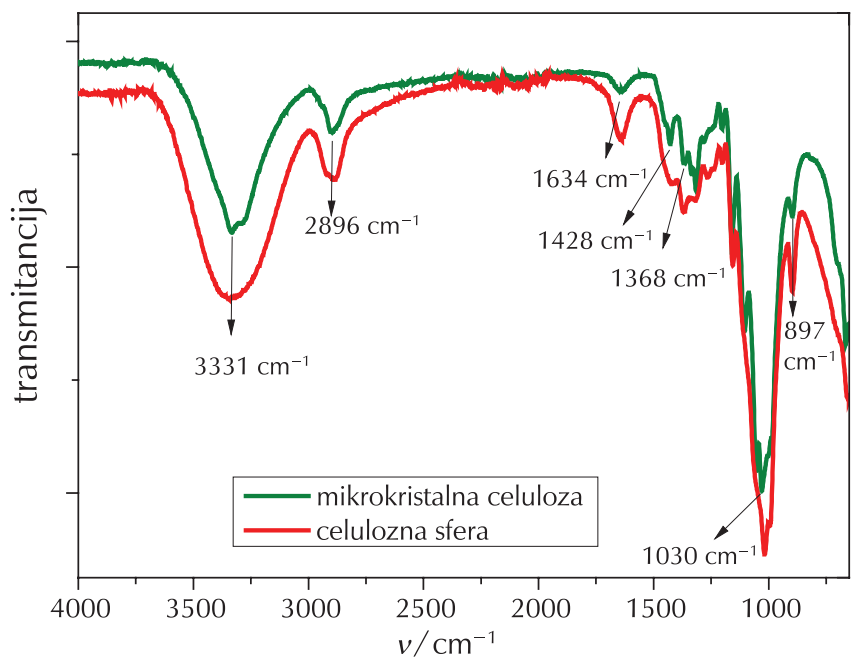

Slika 2 - Usporedba infracrvenih spektara mikrokristalne celuloze (MC) i celulozne sfere (CS)

Fig. 2 - Comparison of infrared spectra of microcrystalline cellulose $(\mathrm{MC})$ and cellulose sphere (CS)

\subsubsection{Odredivanje relativnog udjela PDMAEMA u hidrogelovima infracrvenom spektroskopijom}

Prethodno osušeni hidrogelovi u obliku sfera analizirani su infracrvenom spektroskopijom. Za usporedbu su snimljeni i infracrveni spektri mikrokristalne celuloze, celulozne sfere kao i DMAEMA monomera i umreživala MBA. Infracrveni spektri uzoraka prikazani su na slikama $2-4$. $\mathrm{U}$ infracrvenom spektru mikrokristalne (MC) celuloze (slika 2) uočeni su sljedeći signali: široki signal na $3331 \mathrm{~cm}^{-1}$ je vrpca od vibracija hidroksilne skupine u polisaharidu na koju utječu intra- i intermolekulske vodikove veze, vrpca na $2896 \mathrm{~cm}^{-1}$ pripada vibraciji veza $\mathrm{CH}$, vrpca na $1634 \mathrm{~cm}^{-1}$ odgovara vibracijama molekula vode apsorbirane u celulozi, vrpce na 1428 i $1030 \mathrm{~cm}^{-1}$ karakteristične su za celulozu i pripadaju redom vibracijama skupina $\mathrm{CH}_{2}$ i OH u celulozi, vrpca na $897 \mathrm{~cm}^{-1}$ odgovara vibraciji karakteristične $\beta$ - $(1 \rightarrow 4)$ glikozidne veze. Na istoj slici dan je i usporedni IR spektar celulozne sfere osušene metodom ekstrakcije zamrzavanjem. Jedina značajnija razlika u spektru zabilježena je u području $1425-1230 \mathrm{~cm}^{-1}$ što je vjerojatno posljedica promjena u kristalnoj strukturi celuloze odnosno može se pripisati drugačijem rasporedu inter- i intramolekularnih vodikovih veza unutar struktura celuloze u ta dva oblika.

FTIR spektri monomera DMAEMA i umreživala MBA prikazani su na slici 3. U infracrvenom spektru monomera DMAEMA vidljiv je signal na $2949 \mathrm{~cm}^{-1}$ koji odgovara sp ${ }^{3}$ vibraciji veze $\mathrm{CH}$. Signali na 2822 i $2770 \mathrm{~cm}^{-1}$ također odgovaraju sp ${ }^{3}$ vibracijama veze $\mathrm{CH}$, ali unutar $\mathrm{N}\left(\mathrm{CH}_{3}\right)_{2}$ skupine. Signal koji se nalazi na $1717 \mathrm{~cm}^{-1}$ odgovara vibraciji karbonilne skupine, dok je na $1638 \mathrm{~cm}^{-1}$ vidljiv signal koji pripada vibraciji veze $\mathrm{C}=\mathrm{C}$.

Na temelju omjera intenziteta karakteristične vrpce za PDMAEMA (vrpca skupine $\mathrm{C}=\mathrm{O}$ ) i karakteristične vrpce za celulozu (vrpca $\beta-(1 \rightarrow 4)$ glikozidne veze) procijenjen je relativni udio poli(dimetilaminoetil-metakrilata) (PDMAE-

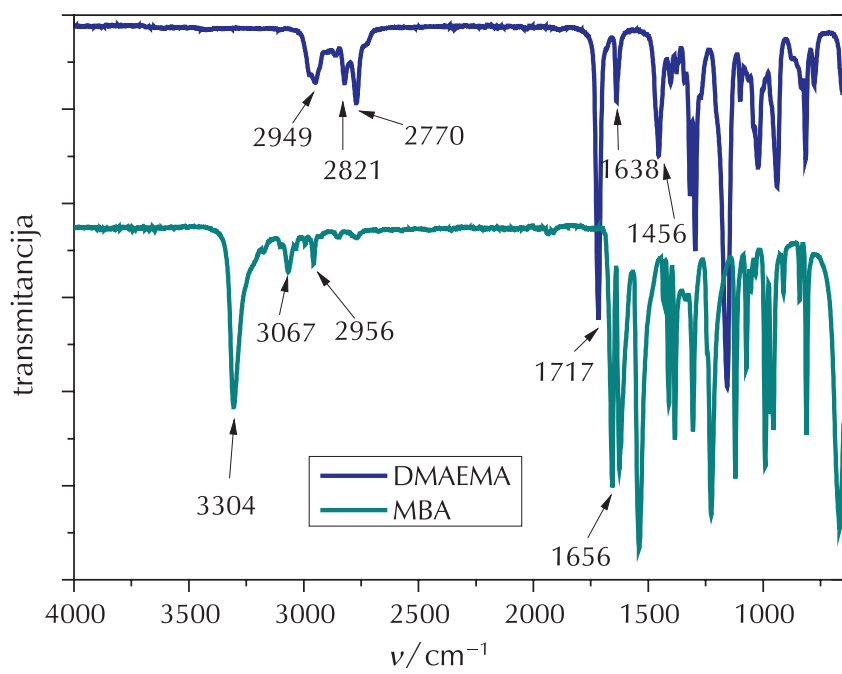

Slika 3 - Infracrveni spektri monomera DMAEMA i umreživala MBA

Fig. 3 - Infrared spectra of DMAEMA monomer and MBA crosslinker

MA) u nastalim hidrogelovima $\left(I_{1724 / 897}\right)$. Na slici 4 prikazani su infracrveni spektri hidrogelova HG1 i HG3 - HG5. U svim hidrogelovima se uz vrpce prisutne u celulozi pojavljuje i vrpca pri oko $1724 \mathrm{~cm}^{-1}$ koja ukazuje na prisustvo karbonilne skupine PDMAEMA. Sastav sintetiziranih hidrogelova dan je u tablicama 1 i 2.

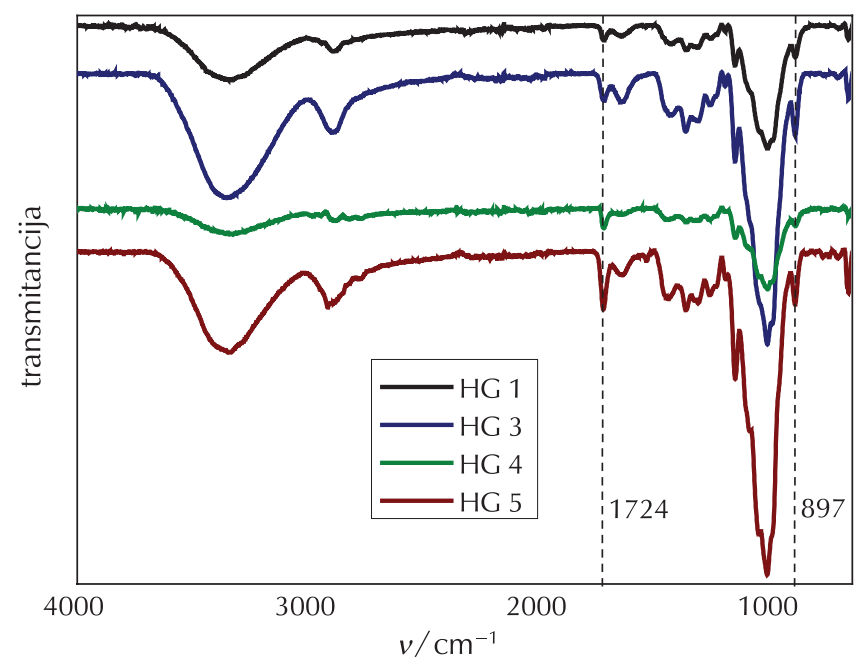

Slika 4 - Infracrveni spektri hidrogelova HG1, HG3-HG5

Fig. 4 - Infrared spectra of HG1, HG3-HG5 hydrogels

\subsubsection{Ovisnost sastava o postupku priprave hidrogelova}

U tablici 1 prikazani su sastavi hidrogelova koji su usporedno pretaloživani u vodi i etanolu, pri čemu je ustanovljena velika razlika u sadržaju PDMAEMA. Vjerojatno objašnjenje je da prilikom polimerizacije DMAEMA monomera uz graftiranje na prstenove celuloze jednim dijelom na- 
Tablica 1 - Sastav hidrogelova sinteziranih uz različit redoslijed dodavanja monomera i inicijatora, koji su pretaloživani u vodu i etanol

Table 1 - Composition of hydrogels synthesized with different order of addition of monomers and initiators, precipitated into water and ethanol

\begin{tabular}{c|c|c|c|c|c|c}
\hline & Oznaka uzorka & $n($ Cel $) / n($ DMAEMA) & $n($ Cel) $/ n($ MBA $)$ & $t$ (polimerizacije) $/ \mathrm{h}$ & Pretaloživanje & $I_{1724 / 897}$ \\
\hline \multirow{3}{*}{ Prvo monomer } & HG 1 & $1: 1$ & $5: 1$ & 5 & voda & 0,46 \\
\cline { 2 - 7 } & HG 1 e & $1: 1$ & $5: 1$ & 5 & etanol & 2,8 \\
\hline \multirow{2}{*}{ Prvo inicijator } & HG 2 & $1: 1$ & $5: 1$ & 5 & voda & 0,31 \\
\cline { 2 - 7 } & HG 2e & $1: 1$ & $5: 1$ & 5 & etanol & 2,3 \\
\hline
\end{tabular}

Tablica 2 - Sastav reakcijske smjese, trajanje reakcije polimerizacije i omjeri intenziteta vrpci karbonilne skupine i glikozidne veze u postupku priprave hidrogelova

Table 2 - Composition of reaction mixture, duration of polymerization reaction, and intensity ratio of carbonyl group and glycosidic bond in prepared hydrogels

\begin{tabular}{c|c|c|c|c}
\hline Oznaka uzorka & $n($ Cel $) / n($ DMAEMA $)$ & $n($ Cel $) / n($ MBA $)$ & $t$ (polimerizacije) $/ \mathrm{h}$ & $I_{1724 / 897}$ \\
\hline HG 1 & $1: 1$ & $5: 1$ & 5 & 0,46 \\
\hline HG 3 & $1: 1$ & $5: 1$ & 5 & 0,44 \\
\hline HG 4 & $1: 3$ & $5: 1$ & 5 & 1,10 \\
\hline HG 5 & $1: 3$ & $2,5: 1$ & 5 & 1,10 \\
\hline HG 6 & $1: 1$ & 5,45 \\
\hline
\end{tabular}

staje i slobodni homopolimer PDMAEMA. Homopolimer PDMAEMA dobro je topljiv u vodi, dok je etanol lošije otapalo za PDMAEMA. Nakon pretaloživanja u vodi dolazi do potpunog uklanjanja PDMAEMA, dok je u slučaju etanola uklanjanje nepotpunije, što za posljedicu ima veći sadržaj uklopljenog PDMAEMA u hidrogelu, kao što to omjeri $l_{1724 / 897}$ pokazuju. Nadalje, u prvim pokusima inicijator je dodavan otopini celuloze s namjerom da se aktiviraju $\mathrm{OH}$ skupine celuloze, a naknadno su dodavani monomer DMAEMA i umreživalo MBA (HG 2). Nakon toga redoslijed je promijenjen tako da su u otopinu celuloze najprije dodani monomer i umreživalo, a na kraju inicijator. Pokazalo se da se na taj način povećao sadržaj PDMAEMA u hidrogelu (HG 1). Slijedeći drugu proceduru, kod pretaloživanja u vodu sadržaj PDMAEMA se povećao, što je vidljivo iz gotovo 50 \%-tnog povećanja omjera intenziteta (HG 1 vs. HG 2), dok je u slučaju pretaloživanja u etanol zabilježeno povećanje od oko 22 \% (HG 1e vs. HG 2e).

Ispitan je utjecaj i vremena trajanja reakcije na udio PDMAEMA u hidrogelu (tablica 2). Na temelju dobivenih rezultata vidljivo je da skraćenjem reakcije s pet na tri sata (HG 1 vs. HG 3 i HG 4 vs. HG 5) ne dolazi do značajnije promjene u omjeru intenziteta IR vrpci, što ukazuje na to da se ne mijenja sastav nastalog produkta. Također, pri sintezi hidrogelova mijenjan je omjer celuloze i dimetilaminoetil-metakrilata (DMAEMA) te omjer celuloze i umreživala $\mathrm{N}, \mathrm{N}$-metilen-bis-akrilamida (MBA). Na temelju procijenjenog sadržaja PDMAEMA pomoću infracrvene spektroskopije u prvim hidrogelovima povećan je omjer celuloza/DMAEMA kako bi se povećao udio PDMAEMA u kasnije priređenim hidrogelovima. Na taj način došlo je do značajne promjene omjera intenziteta IR vrpci (s 0,46 za HG 1 na 1,1 za HG 4), što ukazuje na povećani udio PDMAEMA u hidrogelu. Povećanje udjela MBA u reakcijskoj smjesi nije utjecalo na udio PDMAEMA u hidrogelu, kao što pokazuju vrijednosti omjera intenziteta (HG 1 i HG 6).

\subsection{Priprava i karakterizacija srebrovih nanočestica}

Koloidno srebro ima dobra svojstva kao što su: dobra električna i toplinska vodljivost, kemijska stabilnost te antibakterijsko djelovanje. Zbog antibakterijskih svojstava srebra zanimljivo je istražiti mogućnosti ugradnje srebrovih nanočestica u celulozne hidrogelove s obzirom na potencijalnu primjenu u medicinske svrhe. Sinteza nanočestica srebra u ovom radu provedena je na dva načina: a) zelena sinteza $\mathrm{Ag}$ nanočestica redukcijom $\mathrm{Ag}^{+} \mathrm{s}$ ekstraktom ružmarina i b) sinteza nanočestica srebra in situ na pripravljenom hidrogelu kroz redukciju $\mathrm{Ag}^{+} \mathrm{s}$ tercijarnim aminoskupinama prisutnim u PDMAEMA.

U interakciji svjetla (fotona) s površinskim plazmonima dolazi do kolektivne ekscitacije površinskih plazmona. Ekscitacija površinskih plazmona na nanočesticama srebra izaziva intenzivno žuto obojenje suspenzije. Valna duljina maksimuma apsorpcije plazmona, $\lambda_{\max }$ ovisna je o veličini i obliku metalnih nanočestica. Poznato je da se s porastom veličine čestica signal plazmona pomiče prema većim valnim duljinama i postaje širi. Vrijednosti veličina čestica srebra i parametri UV-Vis spektra priloženi su u tablici $3 .{ }^{20,21}$

Tablica 3 - Veličina srebrovih nanočestica i karakteristike UV-Vis spektra koloidne otopine srebra ${ }^{21}$

Table 3 - Silver nanoparticle size and characteristics of UV-Vis spectrum of colloidal silver solution

\begin{tabular}{c|c|c}
\hline Veličina čestica/nm & $\lambda_{\max } / \mathrm{nm}$ & $\begin{array}{c}\text { Širina na polovici } \\
\text { visine signala/nm }\end{array}$ \\
\hline $10-14$ & $395-405$ & $50-70$ \\
\hline $35-50$ & 420 & $100-110$ \\
\hline $60-80$ & 438 & $140-150$ \\
\hline
\end{tabular}




\subsubsection{UV-Vis analiza suspenzije srebrovih nanočestica}

Sinteza nanočestica srebra provedena je uz upotrebu ekstrakta ružmarina kao reducensa pri sobnoj temperaturi $\left(24{ }^{\circ} \mathrm{C}\right)$. Pojava žuto-smeđe boje u do tada bezbojnoj otopini srebrova nitrata prvi je indikator nastanka nanočestica srebra. Promjena boje otopine posljedica je fenomena rezonancije površinskih plazmona. ${ }^{20}$ Karakterizacija pripravljenih suspenzija provedena je UV-Vis spektroskopijom, tehnikom prikladnom za utvrđivanje prisutnosti čestica i njihovih svojstava. Poznato je da na spektar nanočestica utječe veličina, oblik i međudjelovanje čestica, gustoća slobodnih elektrona i okolni medij. Interakcija vidljive svjetlosti s površinskim plazmonima izazvat će apsorpciju zračenja u području valnih duljina koje odgovaraju frekvenciji površinskih plazmona. $U$ određenim vremenskim intervalima (10, 20, 30, 45 i 60 min) uzimani su alikvoti reakcijske smjese te je UV-VIS spektroskopijom praćena sinteza nanočestica srebra. Rezultati praćenja sinteze nanočestica srebra prikazani su na slici 5 . Iz rezultata je vidljivo da se kod $423 \mathrm{~nm}$ javlja signal koji odgovara području u kojem se javljaju signali maksimuma apsorbancije plazmona nanočestica srebra, što je poznato iz literature ${ }^{21}$ (tablica 3). Postojanje signala u UV-Vis spektru ukazuje na uspješnu redukciju $\mathrm{Ag}^{+}$iona s ekstraktom ružmarina i prisustvo nanočestica srebra u uzorku. Sa slike 5 vidljivo je da se intenziteti signala pravilno povećavaju s vremenom, praćeno kroz 60 min, gdje jedino odstupa intenzitet signala uzorka mjerenog nakon $10 \mathrm{~min}$. Intenzitet tog signala ima maksimalnu apsorbanciju pri nešto nižoj valnoj duljini $(410 \mathrm{~nm})$ u odnosu na preostale uzorke koji pokazuju maksimum na većim vrijednostima (423 nm). Na temelju manjeg intenziteta signala uzorka nakon 10 min u odnosu na signal uzorka nakon 20 min te pomaka vrha signala prema većim vrijednostima (s 410 na $423 \mathrm{~nm}$ ) može se pretpostaviti da je došlo do rasta manjih čestica nastalih na početku reakcije te je posljedično smanjena njihova koncentracija.

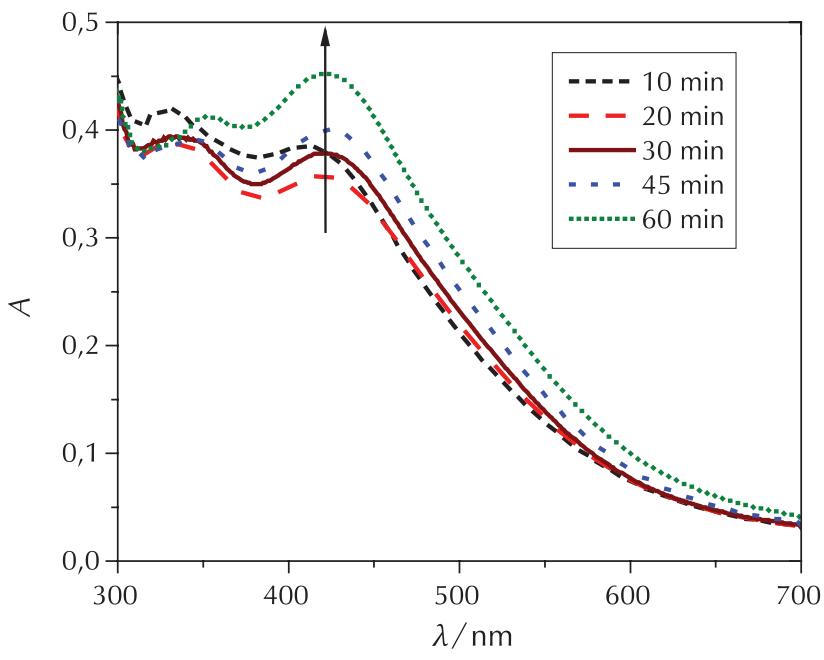

Slika 5 - UV-Vis spektar srebrovih nanočestica pripravljenih pri sobnoj temperaturi s ekstraktom ružmarina kao reducensom

Fig. 5 - UV-Vis spectrum of silver nanoparticles prepared at room temperature with rosemary extract as reducing agent

\subsection{Ispitivanje morfologije uzoraka pretražnom elektronskom mikroskopijom}

Pretražnom elektronskom mikroskopijom (SEM) ispitana je morfologija celulozne sfere i hidrogelova HG 1 i HG 6, osušenih metodom ekstrakcije zamrzavanjem. HG 1 i HG 6 imaju iste početne omjere celuloza/DMAEMA monomer i vrlo bliske udjele PDMAEMA u hidrogelu kao što to IR rezultati pokazuju (tablica 2). Međutim, udio umreživala u HG 6 dvostruko je veći u odnosu na HG 1, a povezano s time može se zabilježiti drugačija poroznost. Hidrogelovi pripravljeni na taj način imali su mekanu strukturu za razliku od uzoraka pripravljenih sušenjem u sušioniku koje karakterizira zbijena, tvrda struktura. SEM mikrografija celulozne sfere (slika 6) pokazuje hrapavu vanjsku površinu i homogenu, glatku površinu u masi sfere. Nasuprot tome, na SEM mikrografijama sfera HG 1 i HG 6 vide se sfere pravilnog oblika (slike 7 i 8). Kod uzorka HG 1 površina sfere blago je hrapava (slika 7a), dok se kod uzorka HG 6 na vanjskoj površini uočavaju brojne pravilne šupljine (slika 8a). Oba uzorka pokazuju veliku poroznost po cijelom presjeku sfere (slike $7 b$ i 8b), što objašnjava bitno drugačija mehanička svojstva uzoraka sušenih ekstrakcijom zamrzavanjem hidrogelova.
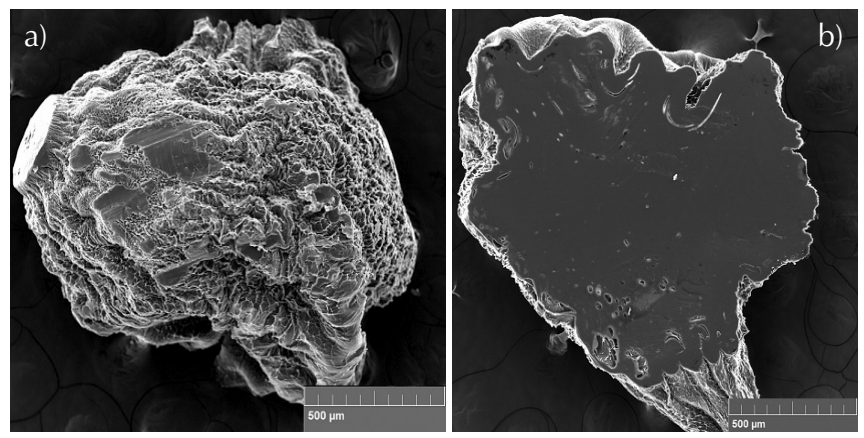

Slika 6 - Morfologija sfere celuloze osušene metodom ekstrakcije zamrzavanjem: a) ovojnica sfere, b) presjek sfere

Fig. 6 -Morphology of the cellulose sphere dried by freezing extraction method: a) sphere envelope, b) sphere cross-section
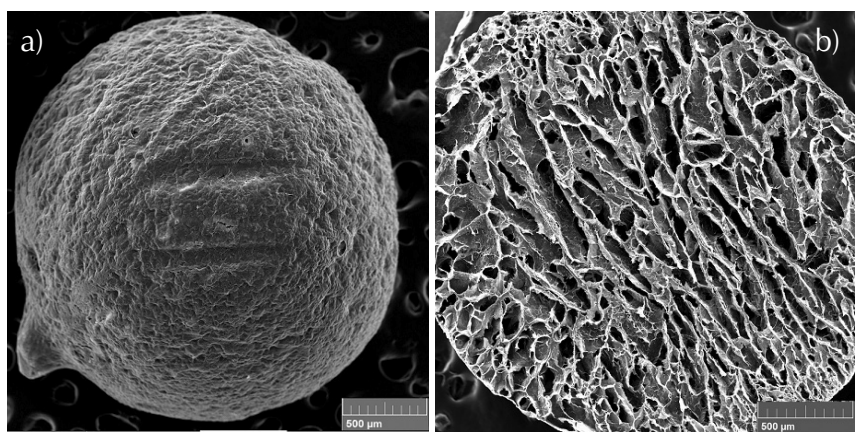

Slika 7 - Morfologija hidrogela HG 1 osušenog metodom ekstrakcije zamrzavanjem: a) ovojnica sfere, b) presjek sfere

Fig. 7 - Morphology of HG 1 hydrogel dried by freezing extraction method: a) sphere envelope, b) sphere cross-section 

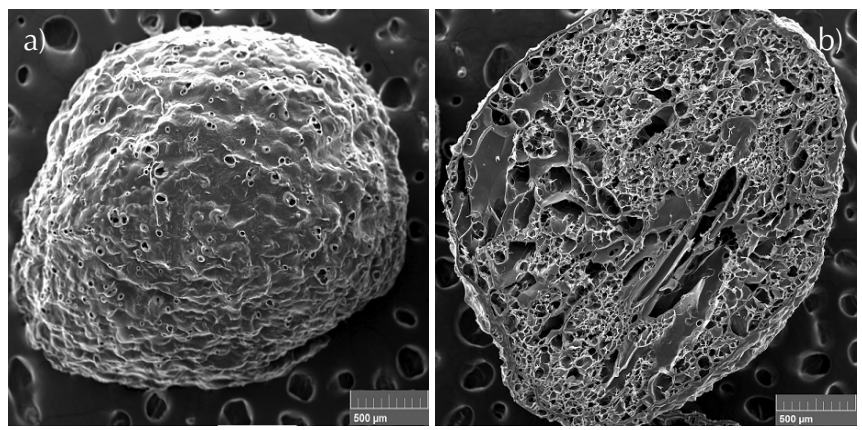

Slika 8 - Morfologija hidrogela HG 6 osušenog metodom ekstrakcije zamrzavanjem: a) ovojnica sfere, b) presjek sfere

Fig. 8 - Morphology of HG 6 hydrogel dried by freezing extraction method: a) sphere envelope, b) sphere cross-section

\subsection{Bubrenje uzoraka}

\subsubsection{Odredivanje stupnja bubrenja uzoraka bubrenih u vodi}

Bubrenje hidrogelova ispitivano je na uzrocima HG $1 \mathrm{i}$ HG 6 a provedeno je u deioniziranoj vodi pri sobnoj temperaturi u trajanju od $4 \mathrm{~h}$. Sfere hidrogelova prethodno su osušene metodom ekstrakcije zamrzavanjem ili u sušioniku. Hidrogelovi sušeni na ta dva načina imaju jednak kemijski sastav, ali se strukturom razlikuju. Sfere hidrogelova osušenih metodom ekstrakcije zamrzavanjem zadržavaju poroznu strukturu (slike 7 i 8), dok se sušenjem u sušioniku sfere smanjuju te imaju kompaktnu strukturu. Također, u vodi je bubrena i celulozna sfera. U njoj nije prisutan PDMAEMA pa je na temelju različitog ponašanja te i sfera hidrogela (HG 1, HG 6) moguće ispitati njegov utjecaj na stupanj bubrenja u hidrogelovima.

Na slici 9 prikazana je promjena stupnja bubrenja u ovisnosti o vremenu za sfere hidrogelova HG 1 i HG 6 i celulozne sfere. Ravnotežni stupanj bubrenja hidrogela HG 1 iznosi oko $505 \%$, dok za hidrogel HG 6, kod kojeg je dodana dvostruko veća količina umreživala MBA, ravnotežni stupanj bubrenja iznosi oko $265 \%$. Smanjenje stupnja bubrenja ukazuje na smanjenje poroznosti sfera, a posljedično i količine zarobljene vode unutar hidrogela. Na temelju toga vidljivo je da udio MBA u hidrogelu znatno utječe na formiranje pora unutar sfere prilikom sušenja ekstrakcijom zamrzavanjem. Sfera celuloze ima još manji stupanj bubrenja u odnosu na odabrane hidrogelove, koji iznosi oko $79 \%$, s obzirom na to da unatoč sušenju metodom ekstrakcije zamrzavanjem nije nastala porozna struktura, što je vidljivo iz SEM mikrografa (slika 6). Vrijeme koje je bilo potrebno za postizanje maksimalnog stupnja bubrenja kod HG 1 iznosi oko 90 min, a za HG 6 oko 45 min. Na površini ovojnice HG 6 prisutne su šupljine koje omogućavaju brži prolazak vode u unutrašnjost, za razliku od HG 1 čija ovojnica djeluje zatvoreno. Budući da HG 1 ima porozniju unutrašnjost u odnosu na HG 6, ima i veću mogućnost zadržavanja većih količina vode.

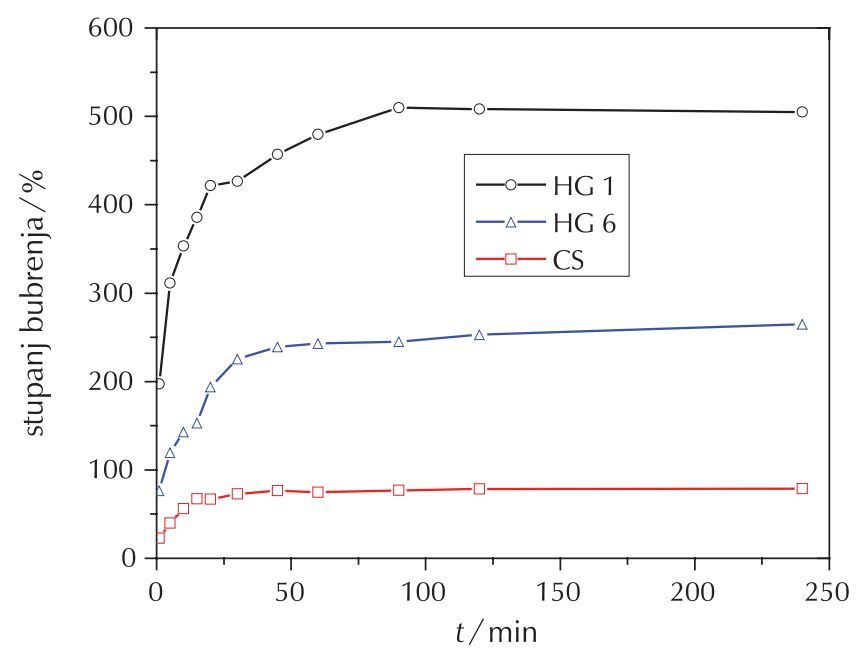

Slika 9 - Prikaz stupnja bubrenja u ovisnosti o vremenu za hidrogelove HG 1 i HG 6 osušene metodom ekstrakcije zamrzavanjem te za celuloznu sferu

Fig. 9 -Time dependence of the degree of swelling for HG 1 and HG 6 hydrogels dried by freezing extraction method, and for the cellulose

Na slici 10 grafički je prikazana ovisnost stupnja bubrenja o vremenu za sfere HG 1 i HG 6 osušenih u sušioniku. Kod tog načina sušenja dobiva se kompaktna struktura uzoraka za razliku od poroznih struktura unutar sfera istih uzoraka sušenih ekstrakcijom zamrzavanjem. Određivanjem stupnja bubrenja uzoraka sušenih u sušioniku koji imaju kompaktnu strukturu do izražaja dolazi doprinos kemijskog sastava hidrogela. Na slici 10 prikazana je i ovisnost stupnja bubrenja celulozne sfere koja ima kompaktnu i neporoznu unutrašnjost, unatoč tome što je sušena metodom ekstrakcije zamrzavanjem, pa se može uspoređivati sa sferama hidrogelova koje su također neporozne. Vrijednosti ravnotežnog stupnja bubrenja HG 1 i HG 6 vrlo su slične, a u odnosu na celuloznu sferu veće su za približno $37 \%$. Na temelju omjera IR vrpci za te je hidrogelove procijenjen gotovo jednak udio PDMAEMA. Istodobno, prilikom sinteze HG 6 dodana je dvostruko veća količina umreživala MBA u odnosu na HG 1, ali ti rezultati bubrenja ukazuju da udio MBA nije znatno utjecao na ravnotežni stupanj bubrenja dobivenog hidrogela. Za usporedbu, sfere HG 1 imaju ravnotežni stupanj bubrenja oko $109 \%$, koji je višestruko manji od stupnja bubrenja istog hidrogela osušenog metodom ekstrakcije zamrzavanjem (oko $505 \%$ ). Sfere HG 6 koje u sastavu imaju dvostruko veću količinu umreživala i osušene su u sušioniku imaju stupanj bubrenja oko $105 \%$, što je približno 2,5 puta manje od istog hidrogela osušenog metodom ekstrakcije zamrzavanjem sa stupnjem bubrenja oko $265 \%$. Na temelju dobivenih vrijednosti može se zaključiti da je s dodatkom PDMAEMA u hidrogelovima pospješeno bubrenje u odnosu na čistu celulozu. $\mathrm{Na}$ ovom primjeru očituje se kako se na ponašanje hidrogelova može utjecati putem strukture koja podrazumijeva omjer celuloze i PDMAEMA, odnosno sadržaj MBA, ali još i više kroz njihov dizajn odnosno povećanjem poroznosti pripravom ekstrakcijom zamrzavanjem. 


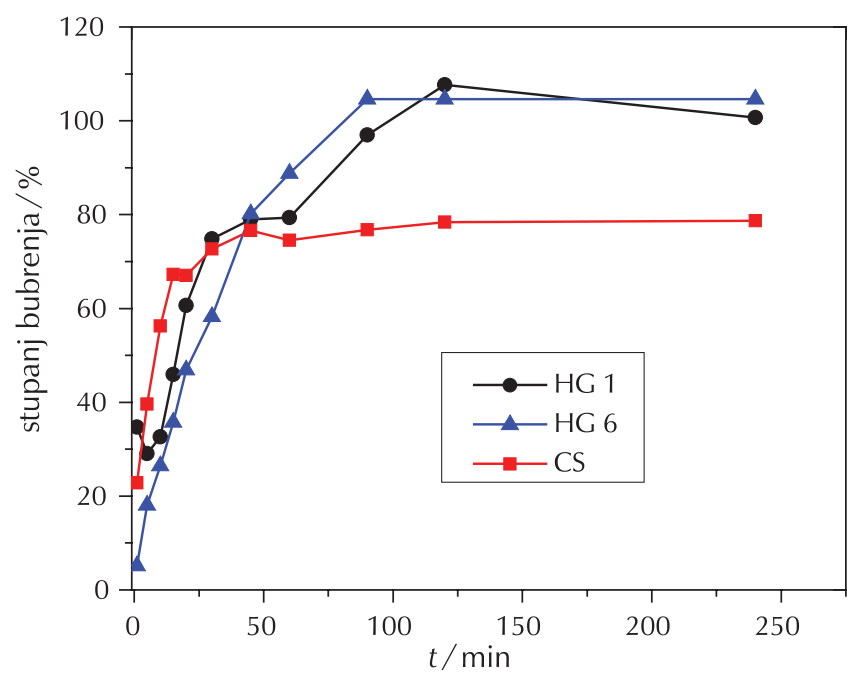

Slika 10 - Prikaz stupnja bubrenja u ovisnosti o vremenu za hidrogelove HG 1 i HG 6 osušene u sušioniku te za celuloznu sferu

Fig. 10 - Time dependence of the degree of swelling for HG 1 and HG 6 hydrogels dried in the dryer, and for the cellulose sphere

\subsubsection{Određivanje morfologije i sadržaja srebrovih nanočestica u uzorcima bubrenim u suspenziji srebrovih nanočestica ili otopini $\mathrm{AgNO}_{3}$}

Pretražnom elektronskom mikroskopijom ispitana je morfologija celuloznih sfera i odabranih hidrogelova prethod- no nabubrenih u suspenziji nanočestica srebra ili otopini srebrova nitrata. Nakon bubrenja svi su uzorci osušeni metodom ekstrakcije zamrzavanjem. Prisutnost srebra na površini i u unutrašnjosti hidrogelova određena je pomoću energijsko disperzivnog spektrometra (EDS). Uzorci su prerezani na pola kako bi se mogla utvrditi razlika u sadržaju srebrovih nanočestica između površine i unutrašnjosti uzoraka (slike 11 i 12).

\section{Hidrogelovi bubreni s prethodno sintetiziranim nanočesticama}

Vrijednosti udjela srebra prisutnog na vanjskoj ovojnici i u unutrašnjosti presjeka sfere uzorka za pripravljene hidrogelove HG 1 i HG 6 i celuloznu sferu dane su u tablici 4 . EDS analiza celulozne sfere bubrene u suspenziji nanočestica srebra pokazala je da niti na površini ni u unutrašnjosti sfere nije prisutno srebro. Nadalje, kod uzorka HG 1 ustanovljeno je prisustvo srebra samo na vanjskoj površini sfere, ali ne i u unutrašnjosti sfere. Kod uzorka HG 6 dokazana je prisutnost srebra i na površini i u unutrašnjosti sfere. Uspoređujući slike 11b i 11c, gdje se jasno vide šupljine u ovojnici hidrogela HG 6, za razliku od hidrogela HG 1 čija ovojnica djeluje u potpunosti zatvoreno, upravo su te šupljine objašnjenje jer omogućavaju prodor čestica srebra u unutrašnjost sfere. Iz rezultata EDS analize te promjene boje hidrogelova nakon bubrenja zaključuje se da prisustvo PDMAEMA u hidrogelovima pospješuje vezivanje srebrovih čestica na sfere hidrogelova.
1
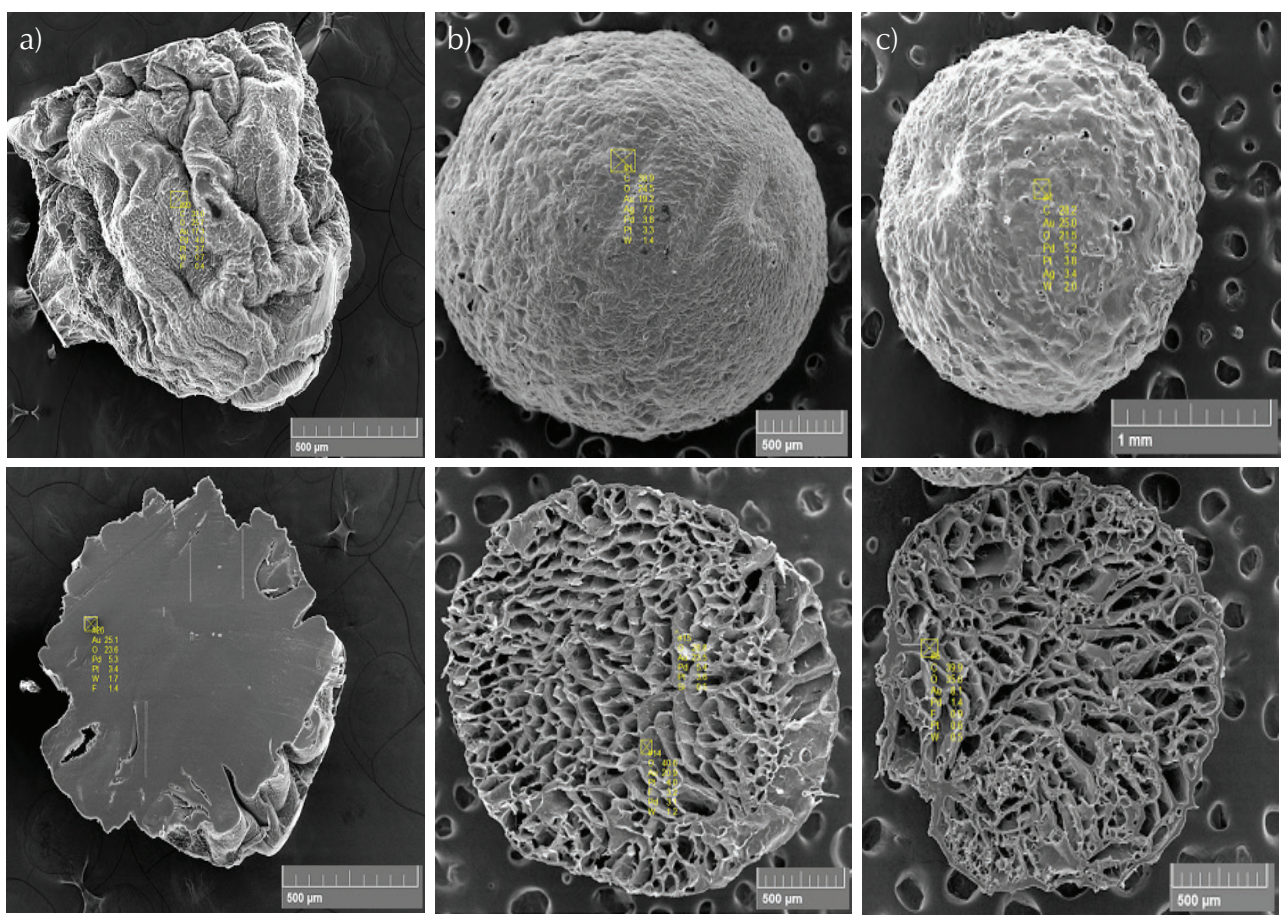

Slika 11 - EDS analiza: a) celulozne sfere, b) hidrogela HG 1, c) hidrogela HG 6 bubrenih u suspenziji nanočestica srebra; 1 - površina, 2 - presjek sfere

Fig. 11 - EDS analysis: a) cellulose sphere, b) HG 1 hydrogel, c) HG 6 hydrogel swollen in suspension of silver nanoparticles; 1 - surface, 2 - cross-section of sphere 

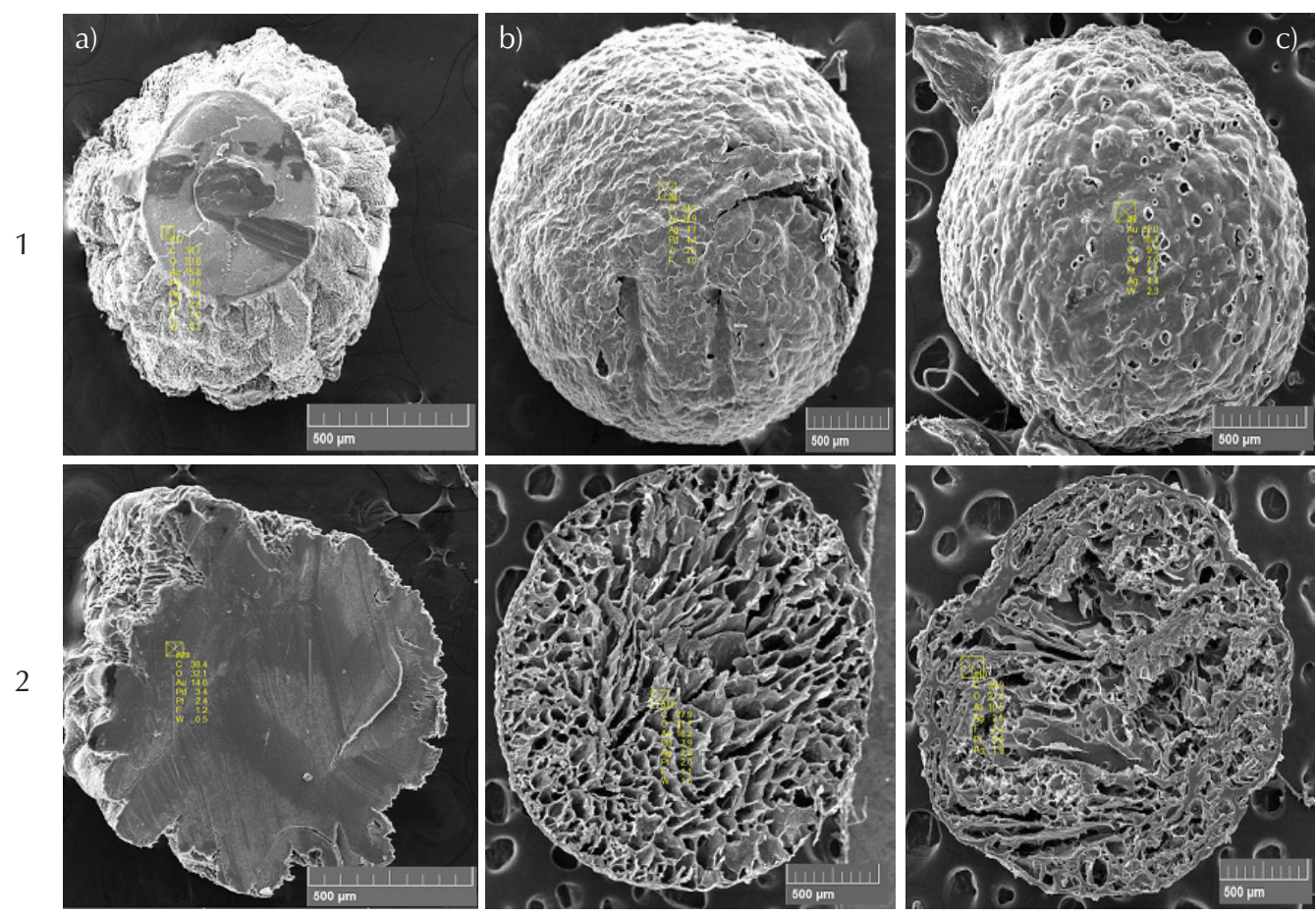

Slika 12 - EDS analiza: a) celulozne sfere, b) hidrogela HG 1, c) hidrogela HG 6 bubrenih u otopini srebrova nitrata; 1 - površina, 2 - presjek sfere

Fig. 12 - EDS analysis: a) cellulose sphere, b) HG 1 hydrogel, c) HG 6 hydrogel swollen in silver nitrate solution; 1 - surface, 2 - cross-section of sphere

Tablica 4 - Rasponi udjela prisutnog srebra u uzorcima bubrenim u suspenziji nanočestica srebra utvrđeni EDS analizom

Table 4 - Ranges of silver content in samples swollen in suspension of silver nanoparticles determined by EDS analysis

\begin{tabular}{c|c|c}
\hline Uzorak & $\begin{array}{c}\text { Udio srebra na vanjskoj } \\
\text { površini }\end{array}$ & $\begin{array}{c}\text { Udio srebra unutar } \\
\text { presjeka }\end{array}$ \\
\hline celuloza & $0 \%$ & $0 \%$ \\
\hline hidrogel 1 & $2,6-7,0 \%$ & $0 \%$ \\
\hline hidrogel 6 & $2,9-5,8 \%$ & $3,2 \%$ \\
\hline
\end{tabular}

\section{Hidrogelovi s in situ sintetiziranim nanočesticama}

Rezultati iz tablice 5 ukazuju da su, nakon bubrenja celulozne sfere $u$ otopini srebrova nitrata, na površini sfere nastale nanočestice srebra. Međutim, u unutrašnjosti sfere nisu detektirane nanočestice srebra, što se objašnjava njihovom kompaktnom strukturom i nemogućnošću difuzije iona srebra. Iz literature je poznato da je moguća reakcija celuloze $\mathrm{s} \mathrm{AgNO}_{3} .{ }^{22}$ Osim na površini celulozne sfere do redukcije $\mathrm{Ag}^{+}$iona došlo je i na sferama HG 1 i HG 6. Kod uzorka hidrogela HG 1 prisutnost srebra utvrđena je i na površini i u unutrašnjosti sfere. Na temelju toga može se pretpostaviti da ioni $\mathrm{Ag}^{+}$prolaze $\mathrm{kroz}$ ovojnicu sfere, raspodjeljuju se po masi sfere te se potom reduciraju i nastaju nanočestice srebra. Kod hidrogela HG 6 također je zabilježena prisutnost čestica srebra na površini i u unutrašnjosti sfere, što je bilo i očekivano s obzirom na prisutnost pora na ovojnici sfere HG 6.
Tablica 5 - Rasponi udjela prisutnog srebra u uzorcima bubrenim u otopini srebrova nitrata utvrđeni EDS analizom

Table 5 - Ranges of silver content in samples swollen in silver nitrate solution determined by EDS analysis

\begin{tabular}{c|c|c}
\hline Uzorak & $\begin{array}{c}\text { Udio srebra na vanjskoj } \\
\text { površini }\end{array}$ & $\begin{array}{c}\text { Udio srebra } \\
\text { unutar presjeka }\end{array}$ \\
\hline celuloza & $2,5-3,4 \%$ & $0 \%$ \\
\hline hidrogel 1 & $2,4-7,4 \%$ & $2,3-6,1 \%$ \\
\hline hidrogel 6 & $2,7-6,0 \%$ & $1,8-4,9 \%$ \\
\hline
\end{tabular}

\section{Zaključak}

U ovom radu provedena je modifikacija celuloze reakcijoms dimetilaminoetil-metakrilatom (DMAEMA). Iz sintetiziranih kopolimera dalje su priređivani hidrogelovi u obliku sfera, a usporedbe radi priređene su sfere čiste celuloze. Početni uvjeti sinteze kopolimera mijenjani su ponajprije s ciljem povećanja sadržaja poli(dimetilaminoetil-metakrilata) (PDMAEMA) u kopolimeru. Također, povećan je sadržaj umreživala metilen-bis-akrilamida (MBA), što nije utjecalo na sadržaj PDMAEMA. Trajanje reakcije polimerizacije skraćeno je s pet na tri sata jer se pokazalo da ne utječe na konverziju i sastav nastalog kopolimera. FTIR rezultati na temelju kojih je praćen relativni sadržaj PDMAEMA u kopolimerima pokazali su da osim početnog sastava reakcijske smjese najveći utjecaj imaju redoslijed dodavanja inicijatora i DMAEMA te medij u koji se reakcijska smjesa pretaložuje (voda ili etanol). Veći sadržaj PDMAEMA 
u kopolimeru bio je kad se najprije dodavao monomer a zatim inicijator. Također, prilikom pretaloživanja kopolimera u vodu sadržaj PDMAEMA u hidrogelu bio je manji u odnosu na etanol. Vjerojatno objašnjenje je da slobodni PDMAEMA, koji u procesu polimerizacije nastaje istodobno uz PDMAEMA graftiran na celulozne prstenove, voda - kao dobro otapalo potpunije uklanja, što rezultira njegovim manjim krajnjim sadržajem u hidrogelu.

Tako priređeni hidrogelovi kao i celulozne sfere dodatno su modificirani uvođenjem srebrovih nanočestica (AgNPs), bilo bubrenjem u prethodno priređenim AgNPs ili bubrenjem u otopini $\mathrm{AgNO}_{3}$, pri čemu dolazi do njegove redukcije i stvaranja AgNPs. Nanočestice srebra pripravljene su pri sobnoj temperaturi uz upotrebu ekstrakta ružmarina kao reducensa. Morfologija i sadržaj srebra na površini i po presjeku sfera praćeni su pomoću SEM i EDS analiza. Pokazalo se da sušenje ekstrakcijom zamrzavanjem rezultira poroznom strukturom, ali samo u slučaju modificiranja celuloze s PDMAEMA, jer kod čiste celulozne sfere nije postignuta porozna struktura. Nadalje, kod uzorka s većim početnim sadržajem DMAEMA i umreživala, osim izražene poroznosti snimljene su i brojne šupljine na površini sfere. U tom uzorku (HG 6) zabilježen je ujednačen sadržaj srebra: u ovojnici sfere od 2,9 do 5,8 \%, a na presjeku sfere $3,2 \%$. Istodobno u unutrašnjosti HG 1 i celulozne sfere sadržaj srebra bio je $0 \%$, odnosno na površini od 2,6 do $7 \%$ i $0 \%$. Ti rezultati pokazuju da homogena ovojnica HG 1 ne dopušta prolaz AgNPs u masu sfere, a kod čiste celuloze razlog je neporozna struktura. Rezultati bubrenja pokazuju da način sušenja hidrogelova ima velik utjecaj na njihovu sposobnost bubrenja. Tako oba uzorka hidrogelova osušena u sušioniku imaju sličan stupanj bubrenja, oko 100 \%, dok uzorci osušeni metodom ekstrakcije zamrzavanjem pokazuju znatno veće vrijednosti stupnja bubrenja. Tako, najmanji stupanj bubrenja ima sfera celuloze $(80 \%)$, dok hidrogel s većom količinom MBA ima stupanj bubrenja oko $265 \%$, a onaj s manjom količinom MBA ima stupanj bubrenja oko $505 \%$.

\section{Literatura \\ References}

1. D. Klemm, B. Heublein, H.-P. Fink, A. Bohn, Cellulose: fascinating biopolymer and sustainable raw material, Chem. Inform. 44 (2005) 3358-3393, doi: https://doi.org/10.1002/ anie. 200460587.

2. A. M. Bochek, Effect of hydrogen bonding on cellulose solubility in aqueous and nonaqueous solvents, Russ. J. Appl. Chem. 76 (2003) 1711-1719, doi: https://doi. org/10.1023/B:RJAC.0000018669.88546.56.

3. S. M. Fijul Kabir, P. P. Sikdar, B. Haque, M. A. Rahman Bhuiyan, A. Ali, M. N. Islam, Cellulose based hydrogel materials: chemistry, properties and their prospective applications - a review, Prog. Biomater. 7 (2018) 153-174, doi: https://doi. org/10.1007/s40204-018-0095-0.

4. J. Shokri, K. Adibkia, Application of cellulose and cellulose derivatives in pharmaceutical industries, Published: pdf (2013), Chapter 3, pp. 47-66, doi: https://doi.org/10.5772/55178.

5. Y. Habibi, Key advances in the chemical modification of nanocelluloses, Chemic. Soc. Rev. 43 (2014) 1519-1542, doi: https://doi.org/10.1039/C3CS60204D.
6. B. Huang, Q. L. Lu, L. R. Tang, Research progress of nanocellulose manufacture and application, J. For. Eng. 1 (2016) 1-9, doi: https://doi.org/10.13360/j.issn.20961359.2016.05.001.

7. Y.-Y. Li, B. Wang, M.-G. Ma, B. Wang, Review of recent development on preparation, properties, and applications of cellulose-based functional materials, Int. J. Polym. Sci. 2018, Article ID 8973643, 18 pages, doi: https://doi. org/10.1155/2018/8973643.

8. C. Zhou, Q. Wu, Recent Development in Applications of Cellulose Nanocrystals for Advanced Polymer-Based Nanocomposites by Novel Fabrication Strategies, Nanocrystals - Synthesis, Characterization and Applications, Sudheer Neralla, IntechOpen, Chapter 6, 2012, pp. 103-119, doi: https://doi.org/10.5772/48727.

9. D. Roy, M. Semsarilar, J. T. Guthrie, S. Perrier, Cellulose modification by polymer grafting: a review, Chem. Soc. Rev. 38 (2009) 2046-2064, doi: https://doi.org/10.1039/b808639g.

10. X. Liu, Y. Wen, J.i Qu, X. Geng, B. Chen, B. We, B. Wu, S. Yang, $H$. Zhang, Y. Ni, Improving salt tolerance and thermal stability of cellulose nanofibrils by grafting modification, Carbohydr. Polym. 211 (2019) 257-265, doi: https://doi.org/10.1016/j. carbpol.2019.02.009.

11. W. Lin, K. Huang, Y. LiT, Y. Qin, D. Xiong, J. Ling, G. Yi, Z. Tang, J. Lin, Y. Huang, C. Yang, J. Wang, Facile in situ preparation and in vitro antibacterial activity of PDMAEMA-based silver-bearing copolymer micelles, Nanoscale Res. Lett. 14 (2019) 256-267, doi: https://doi.org/10.1186/s11671-0193074-z.

12. E. S. Dragan, Design and applications of interpenetrating polymer network hydrogels. A review, Chem. Eng. J. 243 (2014) 572-590, doi: https://doi.org/10.1016/j.cej.2014.01.065.

13. W. Wei, J. Li, X. Qi, Y. Zhong, G. Zuo, X. Pan, T. Su, J. Zhang, $W$. Dong, Synthesis and characterization of a multi-sensitive polysaccharide hydrogel for drug deliver, Carbohydr. Polym. 177 (2017) 275-283, doi: https://doi.org/10.1016/j.carbpol.2017.08.133.

14. X. F. Zhang, Z. G. Liu, W. Shen, S. Gurunathan, Silver nanoparticles: synthesis, characterization, properties, applications, and therapeutic approaches, Int. J. Mol. Sci. 17 (2016) E1534, doi: https://doi.org/10.3390/ijms17091534.

15. S. Pal, Y. K. Tak, J. M. Song, Does the antibacterial activity of silver nanoparticles depend on the shape of the nanoparticle? A study of the gram-negative bacterium Escherichia coli, Appl. Environ. Microbiol. 73 (2007) 1712-1720, doi: https://doi.org/10.1128/AEM.02218-06.

16. J. S. Kim, E. Kuk, K. N. Yu, J. H. Kim, S. J. Park, H. J. Lee, S. H. Kim, Y. K. Park, Y. H. Park, C. Y. Hwang, Y. K. Kim, Y. S. Lee, D. H. Jeong, M. H. Cho, Antimicrobial effects of silver nanoparticles, Nanomed. 3 (2007) 95-101, doi: https://doi. org/10.1016/j.nano.2006.12.001.

17. S. H. Lee, B. H. Jun, Silver nanoparticles: synthesis and application for nanomedicine, Int. J. Mol. Sci. 20 (2019) 865889, doi: https://doi.org/10.3390/ijms20040865.

18. S. Ahmed, M. Ahmad, B. L. Swami, S. Ikram, A review on plants extract mediated synthesis of silver nanoparticles for antimicrobial applications - A green expertise, J. Adv. Res. 7 (2016) 17-28, doi: https://doi.org/10.1016/j. jare.2015.02.007.

19. V. K. Sharma, R. A. Yngard, Y. Lin, Silver nanoparticles-green synthesis and their antimicrobial activities, Adv. Colloid. Interface. Sci. 145 (2009) 83-96, doi: https://doi.org/10.1016/j. cis.2008.09.002.

20. S. Kurajica, S. Lučić Blagojević, Uvod u nanotehnologiju, Hrvatsko društvo kemijskih inženjera i tehnologa, Zagreb, 2017. 
21. S. D. Solomon, M. Bahadory, A. V. Jeyarajasingam, S. A. Rutkowsky, C. Boritz, Synthesis and study of silver nanoparticles, J. Chem. Educ. 84 (2007) 322-325, doi: https://doi. org/10.1021/ed084p322.

22. F. Fu, J. Gu, J. Cao, R. Shen, H. Liu, Y. Zhang, X. D. Liu, J.
Zhou, Reduction of silver ions using an alkaline cellulose dope: straightforward access to $\mathrm{Ag} / \mathrm{ZnO}$ decorated cellulose nanocomposite film with enhanced antibacterial activities, ACS Sustainable Chem. Eng. 6 (2018) 738-748, doi: https:// doi.org/10.1021/acssuschemeng.7b03059.

\section{SUMMARY \\ Preparation of Cellulose Hydrogels Modified with (2-Dimethylaminoethyl) Methacrylate and Silver Nanoparticles \\ Roko Blažic, Katarina Lenac, and Elvira Vidović*}

Hydrogels are materials displaying the ability to absorb large amounts of water. Cellulose is a widespread, biocompatible, and biodegradable polysaccharide with hydrophilic $\mathrm{OH}$ groups in a structure that allows various modifications. By introducing new functional groups to the repeating units of the polysaccharide chain, it is possible to modify properties of the material in order to prepare hydrogels of desired properties such as antibacterial properties or response to external stimuli. In this work, 2-dimethylaminoethyl methacrylate (DMAEMA) grafting on cellulose was performed. The polymerization of DMAEMA on cellulose was carried out in solvent $N, N$-dimethyl acetamide / LiCl with a peroxide initiator at $90^{\circ} \mathrm{C}$ and $\mathrm{N}, \mathrm{N}$-methylene-bis-acrylamide (MBA) as a crosslinker. Nanoparticles of silver, well known for their antibacterial properties, were also introduced into the prepared hydrogels. The relative proportion of PDMAEMA in hydrogels was determined by infrared spectroscopy. The morphology of the dried samples and the presence of silver were determined by scanning electron microscopy, which showed that the addition of PDMAEMA and drying of the hydrogels by freeze-extraction resulted with a very porous structure. In this way, the binding of silver nanoparticles to hydrogels was also facilitated. Samples of copolymers prepared by drying in a dryer showed a higher degree of swelling in water ( 109\%) than pure cellulose $(80 \%)$. The same materials prepared by freeze-drying formed into porous hydrogels showed much higher swelling rates (256 \% and $505 \%$ ) compared to pure cellulose $(80 \%)$.

\section{Keywords}

Cellulose, (2-dimethylaminoethyl) methacrylate, hydrogel, silver nanoparticle

Faculty of Chemical Engineering and Technology

University of Zagreb

Marulićev trg 19

10000 Zagreb, Croatia
Original scientific paper Received March 18, 2020 Accepted April 14, 2020 